certain limited wars for limited objectives. But in viewing the type of war we fought in World War II, with its saturation bombings to achieve unconditional surrender, and the type of war we would likely fight in the future with thermonuclear weapons, he becomes a relative pacifist. To these wars he thinks the Christian must say No. And if it is said that this means defeat, he replies: "I am skeptical of the meaning of 'victory' and 'defeat' in their relation to modern war between great countries. To my mind the defeat is war itself. In any case it seems to me that there are times when we have no choice but to follow the dictates of our conscience, to throw ourselves on God's mercy, and not to ask too many questions."

This conclusion seems inescapable in the terms of Mr. Kennan's argument. There are things which the religious conscience must reject, and the possible destruction of the human race is chief among them. But the difficulty with this argument is its terms. They are the terms of that absolute either-or morality Mr. Kennan so vigorously rejects when he considers the Cold War, foreign aid, colonialism, and the United Nations. In discussing modern war, and the testing of nuclear weapons, Mr. Kennan triumphantly ig- nores the political complexities and consequences which are the heart of the problem of foreign policy and Christian conscience. Here he operates in a world which prescinds from politics, and in such a world "pure" moral choice becomes easy. In such a world we must all be pacifists.

Only the hopelessly callous, morally cynical man could fail to agree with the Kennan position that a war fought with nuclear weapons of mass destruction, or the war that we fought fifteen years ago, goes far, far beyond any possible limits for the just war. Indeed, it is more and more agreed that the concept of a "just war" is an anachronism, and if we ever really face the dreadful choice of surrender or death, not only for ourselves but possibly for the whole human race, then it would be a curious morality indeed which would sanction our choosing death. But this is not now the issue before us and, God will. ing, it will never be. The issue before us now is to maintain some chance for peace with justice in a world where both are threatened as they have never been before; and, given the facts of Communist power, it is difficult to see how either peace or justice could be maintained were the "Christian" nations unilaterally to disarm. This could be the real moral betrayal.

\title{
correspondence
}

\section{LIBERTY OR DEATH}

New York, N. Y. Sir: According to the April 25th issue of Information Service, you published in your issue of September, 1958 a discussion of an article appearing in the St. Louis Post-Dispatch and a quotation from Hannah Arendt, in general criticizing the action of Congress forbidding the use of government funds to any person or institution who ever proposes or actually conducts any study regarding the surrender of the government of the United States. Might not your position have been stronger if you had advocated action by Congress condemning such persons to jail for incipient treason, for is it not clearly a duty of every citizen of our Nation to support it, if necessary, with his influence, his property, and his life, rather than to accede to defeat by an enemy?
When our armies go out to fight the enemy, all the soldiers do so at the risk of their lives. Just why should civilians back home expect to run no risks, when they are asking their sons to take chances with losing their lives? Can one imagine any position less logical? And what American worth his salt would want to take his chances of keeping alive and existing under the lind of a regime that the Soviets would impose upon us if we were conquered?

May I suggest that you send to Congress apologies for your criticism, and commendations for their action? Qtherwise, you are likely to be indefinitely suspected of treason.

WILLFORD I. KING

Committee for Constitutional Government, Inc. 